\title{
Indocyanine Green-Based Theranostic Nanoplatform for NIR Fluorescence Image-Guided Chemo/Photothermal Therapy of Cervical Cancer [Corrigendum]
}

Ma R, Alifu N, Du Z, et al. Int J Nanomedicine. 2021;16:4847-4861.

The authors have advised due to an error at the time of figure assembly, Figure 6 on page 4858 is incorrect. The correct Figure 6 is shown below.

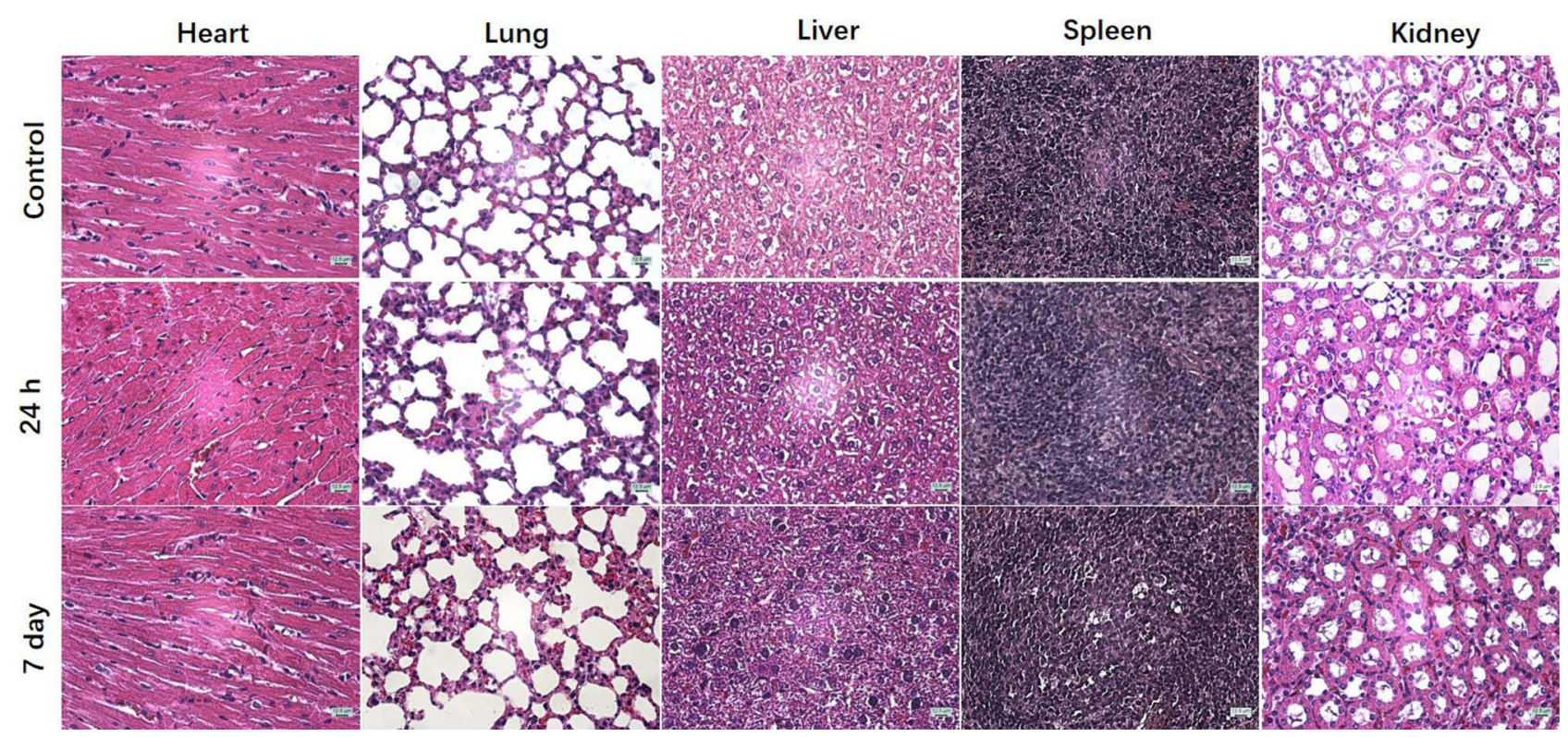

Figure 6 Histological analysis of major organs (heart, liver, spleen, lung, and kidney). BSA@ICG-DOX NPs from treated mice $24 \mathrm{~h}$ after intravenous injection and at day 7 post-injection (counted by ICG concentration). Scale Bar $=12.5 \mu \mathrm{m}$.

The authors apologize for this error and advise it does not affect the results of the paper. 


\section{Publish your work in this journal}

The International Journal of Nanomedicine is an international, peer-reviewed journal focusing on the application of nanotechnology in diagnostics, therapeutics, and drug delivery systems throughout the biomedical field. This journal is indexed on PubMed Central, MedLine, CAS, SciSearch ${ }^{\circledR}$, Current Contents ${ }^{\circledR} /$ Clinical Medicine, Journal Citation Reports/Science Edition, EMBase, Scopus and the Elsevier Bibliographic databases. The manuscript management system is completely online and includes a very quick and fair peer-review system, which is all easy to use. Visit http:// www.dovepress.com/testimonials.php to read real quotes from published authors.

Submit your manuscript here: https://www.dovepress.com/international-journal-of-nanomedicine-journal 